\title{
Project Management of Dynamic Optimization of Business Performance
}

\author{
Zdravko Zekić $^{1}$ \& Luka Samaržija ${ }^{1}$ \\ ${ }^{1}$ Faculty of Economics Rijeka, University of Rijeka, Rijeka, Croatia \\ Correspondence: Luka Samaržija, Faculty of Economics Rijeka, University of Rijeka, Ivana Filipovića 4, Rijeka, \\ Croatia. Tel: 385-51-355-160. E-mail: luka.samarzija@efri.hr
}

Received: September 21, 2012

Accepted: October 16, $2012 \quad$ Online Published: November 7, 2012

doi:10.5539/ibr.v5n12p99

URL: http://dx.doi.org/10.5539/ibr.v5n12p99

\begin{abstract}
The recent business reality is marked by changes which have primarily been caused by the accelerated scientific and technological development, which has made the changes in all segments of the company's environment more dynamic. Continuous innovation and development are becoming the prerequisites of a company's sustainable operation. This implicitly includes the change in the paradigm of business performance and management of a modern company. Instead of determinism, probability and risk have become the context in which the company functions; instead of stability chaos, the area of success; and instead of objectives, profitability and growth the prerequisites of survival and development, the fundamental goals of a modern company. The focus of contemporary entrepreneurial management should be diverted from the continuous repetitive processes towards those based on innovative projects. Project management, as a managerial technology of a systematic management of rounded processes of a project-based approach to development strategy, project realization of development programs and project exploitation of unique and time-limited project products, represents the model of managing the company's flexibility and adaptability to the changes in the environment i.e. the dynamic optimization of business performance and the development of a company's competitiveness.
\end{abstract}

Keywords: project, project-based operations, project management, cost-benefit analysis, dynamic optimization of the company

\section{Introduction}

The dynamics of the changes in all segments of the contemporary company's ever more heterogeneous environment, as prerequisites of survival and development of competitiveness, impose the need for continuous innovation in all processes creating company's added value among which, the most important being, innovation in managerial processes. The traditional management, based on subsequent responses to changes and demands coming from the environment, has become a limiting factor in the sustainability of the company on today's market. Anticipatory management of development changes based on expected changes in the environment has become the conditio sine qua non in developing the company's competitiveness. Project management of strategic business development, as a dynamic system of project-based approach to strategic development, project realization of development programs and project exploitation of project products, imposes itself as an inevitable model of managing the dynamic optimization of a company's business performance and development. Such an approach requires increased organizational flexibility, development of a participative management system, development of an entrepreneurial organizational culture and information support systems that are directed towards potential success and not just the traditional measurement of results of past events. Modern business conditions, mainly determined by the rapid development of information technology which has made the changes in all segments of the company's environment more dynamic, require a complete change in management paradigms. Anticipatory project-based, participative management, focused on implementing intellectual capital within the company's project processes of realizing the balanced system of stakeholders goals, in which the company is seen as a social and economic system within the environmental supra-system, should be the foundation for a new paradigm ensuring sustainability i.e. dynamic optimization of the development of business performance in today's turbulent environment. 


\section{Project vs Process Management of a Company's Business Development}

A company, as a system of creating added value, actually starts its life or exploitation cycle with the project management of strategic business development. The company's life cycle begins with establishment, a project in itself, whereas, its exploitation cycle, with a program of projects related to developing products, technology, organization, conquering markets etc. that are supported by object-oriented investment projects such as office buildings construction, investment in equipment and similar. Various indicators of growth and development show, in general, company's accelerated growth and development at this initial, project run phase of the company's life cycle in which the studies on the viability and expected return on the investments into planned business ventures are completed.

Developed continuous processes of exploiting project products eventually lead to a company's maturity in which periodic oscillations are solved through projects. However, continuous process exploitation of project products leads to culmination of growth, i.e. its degeneration, if not forestalled by new strategic development projects (Adizes, 2006). Liquidation, as the final phase in the company's life cycle is also a project-driven process (Figure 1).

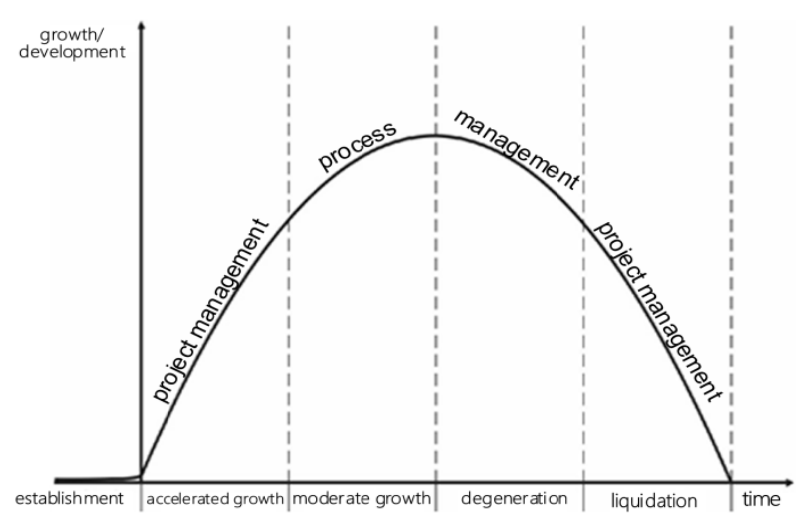

Figure 1. Company's life cycle

The project development gap (Figure 2), i.e. reduced balance between the company's business activities and the changes in the environment, which is reflected in the dynamic decline of the marginal values of growth and development indicators (Kerzner, 2006), i.e. adaptability and flexibility of operations, demands for a continuous project management of development changes of a company's operations. Entrepreneurial management should constantly analyze the company's growth and development curve in order to spot development problems in time and as a result, initiate projects related to reorganization, new product development, introduction of new technologies, conquering of new markets and other projects with the common target of maintaining the life-cycle curve, as long as possible, i.e. constantly, in its growth phase.

A project managed company, by means of a systematically organized chain of projects having direct and indirect economic impacts, and a continuous management of development changes of creating added value for key stakeholders, achieves the dynamic harmonization of its operations and changes within the environment, and thus continuously optimizes the parameters of growth and development, i.e. business performance.

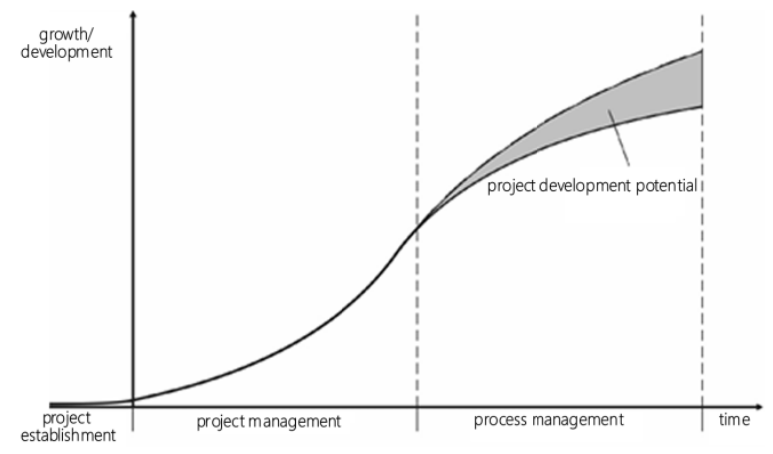

Figure 2. Development potential of project management 
In recent entrepreneurial practice, project management of a company's operations and development i.e. the strategic management of development changes in the company's activities is implemented, as a rule, once the company reaches its culmination stage, i.e. once the crisis degeneration of growth and development occurs (Thomas et al., 2001). The stable conditions of the past century enabled the prolongation of a company's life cycle (Figure 3).

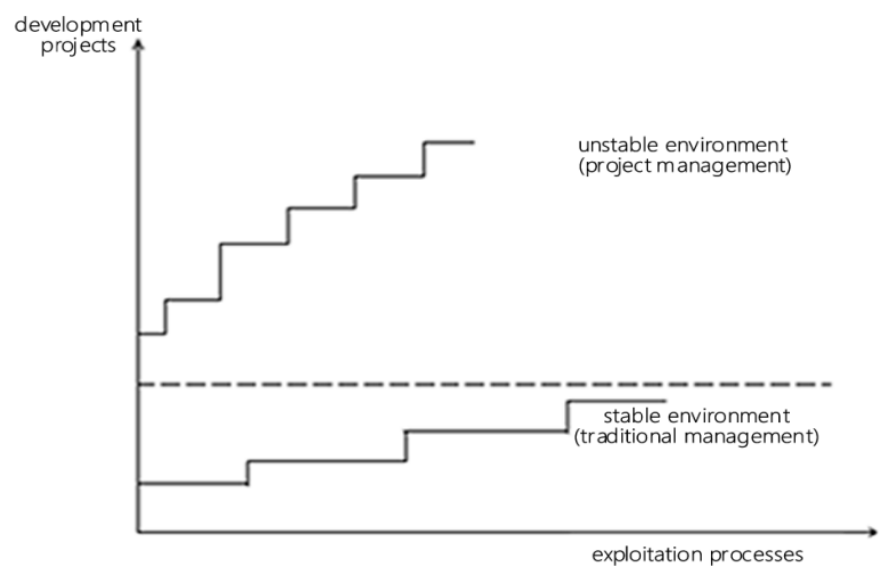

Figure 3. Compatibility of the business environment development and the management concept

Global competition and rapidly changing consumer demands result with the need to change the way in which a company operates. Companies need to dynamically reprogram and improve their business processes in order to meet new challenges (Lida Xu et al., 2008). The contemporary turbulent environment (Figure 3) requires for a continuous project management of business operations and the development of a company as a dynamic systemic process of project preparation strategy, project realization of development programs and project exploitation of project products. In today's environment, strategic project management of competitive abilities emphasizes the importance of analyzing the maturation processes of project management, project portfolio and program projects (Neverauskas et al., 2011). Project portfolio management has become the fundamental ability in managing contemporary project-oriented organizations (Gereis, 2002).

\section{Project Management of Strategic Development of Business}

The process of project management of strategic business development starts with strategic planning of activities leading to a dynamic harmonization of goals and the company's production abilities with the development needs and conditions within its influential environment. Based on the systematic analysis of the environment and the company's resources, the strategy should define the basic directions of a company's development in a planned period as well as the way of achieving goals. The project management's success is crucially dependent on a clearly defined organizational strategy (Maylor, 2001).

A systematic project management of the strategic development of business performance involves strategy design and implementation, project evaluation and control over its realization. The strategy should be transformed into projects, i.e. series of projects related to a company's development. The strategic goals that are planned to be achieved within the strategy need to be converted, first into purpose-based goals, and then into objective goals of company's strategic development projects (Hauc et al., 1991). Once the decision that the strategic development program will be realized through selected projects is brought, it is followed by strategy implementation i.e. project realization of development programs (Figure 4).

Project exploitation of project products provides feedback to the strategic project management on the alignment of objectives and the company's development programs with the development needs and the conditions within the influential environment i.e. the inputs for continuous strategic development of project-based business operations.

The fundamental objective is to ensure strategic advantages over competitors, i.e. to be able to, more efficiently and effectively than the competition, meet the needs and expectations of the company's stakeholders. By having strategic project-oriented goals and time-limited innovation processes, the company continuously ensures new exploitative profit cycles and strengthens its competitiveness in the conditions of constantly discontinuous changes in all segments of its environment. 


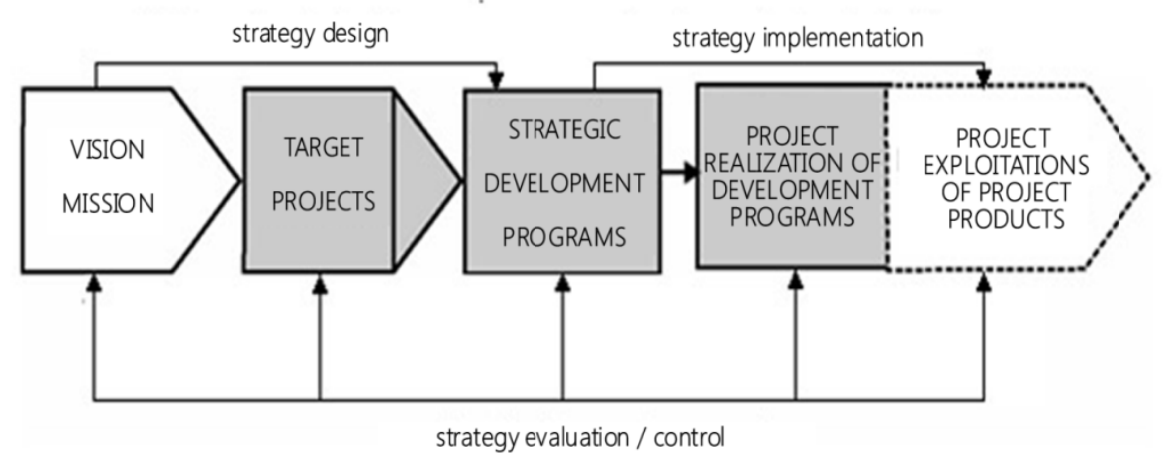

Figure 4. Project management process of strategic development of the company's project based operations

\subsection{Project-based Approach to Development Strategy}

The project-based approach to the company's development strategy in business operations implies the transformation of the vision and mission into target projects and a project-based shaping of corporate strategy, business strategy i.e. business area strategies and individual business function strategies within the strategic development program (Zekić, 2010). Target, stochastic projects related to different strategic scenario-analyses, research of competition's market preferences and trends, as well as similar research projects, represent a starting point in defining the strategic development program projects that help to define the corporate, business and function-related strategies of the company.

In line with the company's vision and mission, target projects define the corporate strategy that should ensure a competitive strategic position of the company on target markets. The corporate strategy is focused on determining the business areas in which the company will operate and to what extent. It is primarily aimed at developing the company's business area portfolio and the synergy between these areas, balancing the flows of profit, risk and cash flows and the expected business results achieved by the company's strategic business units. Technology development projects, projects of investment into new production programs, projects of conquering new markets and other similar projects, synergistically interrelated provide for a company's project-based overall development strategy.

The projects of conquering strategic business units' target markets, projects of diversifying production, projects of rationalizing costs and similar projects define business strategies focused on determining the path to achieving competitive advantages in specific business areas with regards to the objectives of developed strategic business units. Individual business function strategies formulated through projects involved in HR development, quality assurance, automation and digitization of operations and other projects are focused on maximizing resource efficiency and networking the company's activities to support the achievement of the company's business and corporate strategies.

The need for a systematic project-based approach to strategic development of business operations requires that all projects, at the above mentioned strategic levels, are systemically integrated into the strategic project plan, i.e. the strategic development program that defines project management of the strategic development of company's project-based business performance.

In today's turbulent environment, in order to achieve competitive advantages and a strategic relevance of change management projects, the strategic development program, as a result of a project-based approach to the company's development strategy in business operations, places the process of final strategy design at the stage of project realization of development programs (Hauc, 2007). Design and implementation of strategies are organized as an ongoing interactive project-driven process, and as a result, modern project management no longer plays the operational role of effective strategy implementation, but becomes responsible for an effective project preparation and realization of the company's development programs as the basis for the successful exploitation of project products.

\subsection{Project Realization of Development Programs}

Project shaped and hierarchically designed structured business development strategies defined by a company's strategic development program, are implemented through project realization of integral development programs. A successful implementation implies that the planned effectiveness of future operations defined through target projects is accompanied by an effective organizational development of project management of operations and 
company's development (Figure 5).

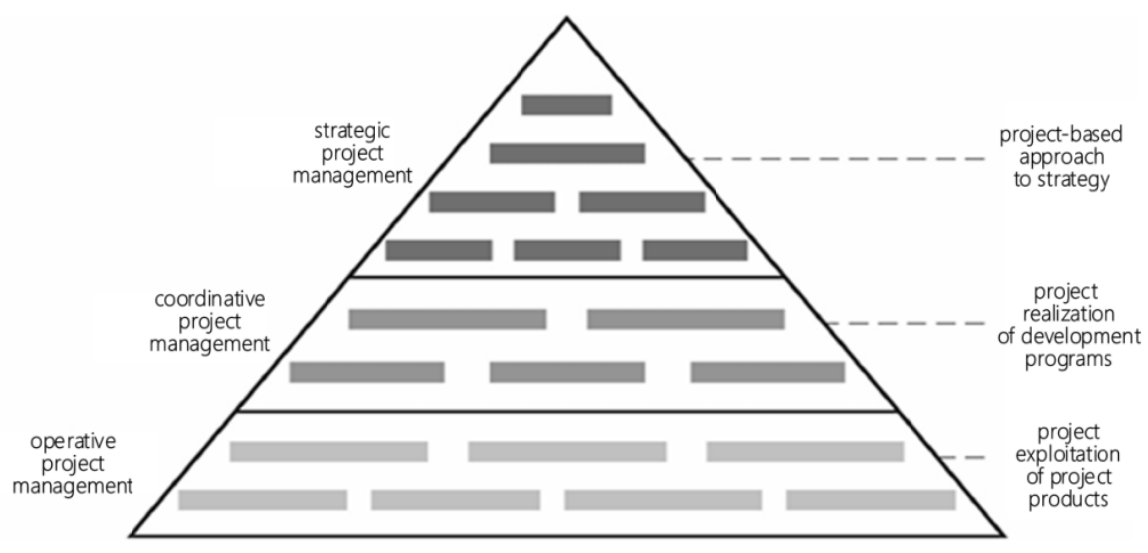

Figure 5. Project management of operations and company's development

Continuity and integrity of the project management process, from strategic to operational level, results in a systematic management of development changes in operations that dynamically optimize the business results of a company as an organization of creating added value for all stakeholders.

Project-based realization of development programs objectifies and implements the development strategy that should through development changes lead to a dynamic optimization of a company's operations. The management of project realization of development programs i.e. integrated multi-project-based development is the original role of project management that by efficiently realizing objective goals of individual projects creates the conditions for fulfilling the purpose of development programs i.e. for effectively meeting the changing needs of company's stakeholders in the project products project exploitation phase.

The systematic project management process, from strategic to coordinative and then operative level, demands for a continuous balancing of respective project activities and objectives in terms of a systematic adjustment of the development strategy of project-based changes within operations i.e. the management of new circumstances in the external and/or internal environment of project realization. Managing project realization of development programs represents the systematic application of knowledge and skills in managing project activities in a manner that effectively and efficiently achieves the objective goals of individual projects that are synergistically interrelated within the defined development program aimed at improving the future success of the company in a strategic business area. Project management in managing the realization of development programs is based on the company's business development strategy, content and objectives of the development program with the aim to determine the objective goals, plans and tactics in the execution of individual development program projects, and which are achieved through an appropriate design of project organization and through management control of project realization.

Project realization of development programs in certain business areas constituting the subsystems of the strategic business development program, is characterized by multi-project operations or project portfolio management. Multi-project management is a concept of leading the project realization of business areas development programs in accordance with the defined company's vision, mission and strategic goals of business development. Successful realization of objective goals of individual projects synergistically interrelated in the realization of target objectives set by the development program is a fundamental prerequisite for the development of business performance in the exploitation phase of project products, whether through continuous or project-driven processes.

Managing development changes in operations is the main concern of project realization of development programs and the fundamental guideline of project management in all phases of its development, from managing individual projects, to managing multi-project operations and to strategic project management of the company's business operations and development. Change is the fundamental guideline in the project-based approach to strategy and the project realization of development programs, and in a great extent, a guideline in the exploitation of project products, a segment that the will have to be more intensively managed based on projects in the conditions determined by today's turbulent environment. 


\subsection{Project Exploitation of Project Products}

The ever more dynamic technological development and the increasingly intensive changes in preferences of the ever more demanding consumers necessitate the development and project exploitation of project products. The products' life cycles and technologies used in their production are becoming shorter, and thus the continuous processes of exploitation, i.e. commercialization of project developed products, more often tend to be substituted by the exploitation processes of project products.

Innovation and temporal determination of target project-based processes are becoming the fundamental source of the contemporary company's competitive development. Project organized logistics, production, marketing and finance, that are systematically integrated and guided towards effective realization of a balanced system of stakeholders' goals, enable the flexibility and adjustment of the company's operations to the changes in the environment and in doing so, dynamically optimize the company's business results. Project management of development changes in operations at the project product exploitation phase completes the system of project management of strategic business development.

"The continuum of change" as an expression of the tendency to achieve desired results by implementing changes at all levels, directs project management towards the project exploitation of project products with the ultimate goal of proving customers with quality products in desired quantities, at the right time, place and price. Project management ensures that the given input produces more output i.e. that the target output is produced at lower input costs. Project management of project-based operations develops the company's strategic competitive advantage by creating added value not merely by a more efficient and effective production of output, but, above all, by developing organizational skills and creativity of employees i.e. by developing the company's entrepreneurial organizational culture which motivates continuous and innovative creation of new added value.

Project exploitation of project products understands a developed project management methodology i.e. a project-based execution of the integrated functions of planning, organization, human resources management and control over project realization. Project management of innovative business development understands an organizationally and professionally developed project management system in the areas of logistics, production, marketing, finance and other business functions within the company. By establishing project chains of logically interconnected activities needed for meeting the objectives of the project realization of project products, are coordinated by project managers, the members of the multi-project management team, that are directed by the project portfolio management, i.e. the company's strategic project management.

Project adjustment of products and services to customers' needs and the targeted flexibility of transformation processes, from the input environment, over the company to the output environment in the project founded and determined scope, timing, quality and cost, dynamically optimize a balanced realization of the objectives of the key interest groups. Achieving dynamic harmony between the company's operations and the changing needs and expectations of its stakeholders in the field of economics, ethics and ecology is a fundamental prerequisite for a successful functioning of a contemporary company, which is most fully realized through project management of business operations and development.

Project management of exploiting project developed products and services, is an anticipatory management based on early information. Project management and execution are, in terms of goals, integrated, innovative and time-limited, and have a developed and opened feedback which includes the effects and activities within the environment i.e. stakeholders' activities in project realization. Early information on the cause of the changes allows the company's timely adjustment and change management towards achieving the fundamental objectives of project realization. Closed feedback, which provides project management with the information about the results of its operations, is the baseline of project management control i.e. directed project exploitation of project products of the company.

Development of project management of exploiting project-based developed products and services is an extremely complex process which presupposes the development of a flexible production technology, project-oriented organization of the company, a developed system of logistics management, from operative to strategic level, and, above all, an organizational culture that motivates organizational learning and innovation, and project-based problem solving. The project management of integrating material, financial, information and transformation flows into a target system of creating added value for all stakeholders, represents the initial premise of designing an organization of project management that manages the development of a modern company business performance. Organizational elimination of all unproductive organizational processes and resources is a fundamental strategic determinant in developing the project management strategy of business performance. 


\section{Designing an Organization for Managing Project Processes}

An effective project management of continuous project-based processes of creating added value for all stakeholders assumes a multidimensional design of a project-based organization with a developed information network and a high degree of participation of projects team members in decision-making processes. Project-based organization of the management system must find a balance between the multiple dimensions of efficiency of organizational functioning. The linear dimension of complex organizations in managing project processes ensures the stability of functioning i.e. it enables the development of specialization and rationalization of operations, whereas the project-based dimension enables flexibility and adaptability to internal and external environmental impacts coming from the project realization environment. Since the project itself is a change, it is opportune to conclude that the appropriate organizations for managing project processes are those organic, dynamic, those that have no sharp borders and strictly prescribed hierarchical structures. Different modes of the matrix organizational structure i.e. network organizations, are suitable organizational mechanisms for the project management of the company's continuous project-based processes in today's environment.

\subsection{Matrix Organizational Structure and Project-based Operations}

When a company develops a multi-project business i.e. when it continuously executes a larger number of projects using well-established methods, it standardizes the processes of project realization and it develops project management methodologies which intensify the substitution of all continuous business activities with project-based processes. A successful management of multi-project processes assumes the development of a matrix organizational structure in which the functional and project organizational structure are interweaved. Depending on the degree of the development of the multi-project-based operations, the matrix organizational structure may contain more functional or project organizational structure features, and thus we talk about weak, strong or balanced matrix structure.

A balanced matrix optimally combines functional and project structure features, in which the functional managers have a significant role in controlling the logistics of project realization and in which there is a sufficient independence and authority of project managers in managing the technology of project goals' realization (Figure 6).

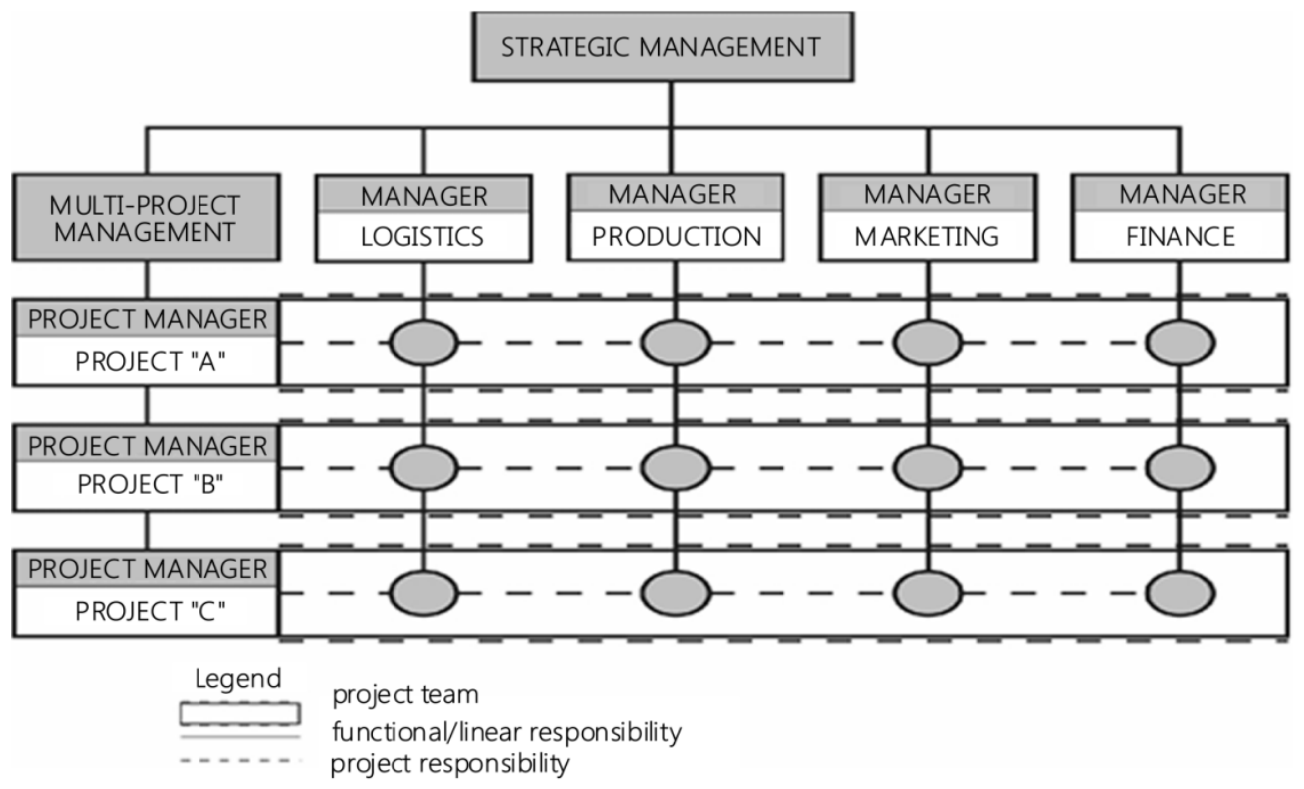

Figure 6. Matrix organizational structure

The optimal solution, for all larger companies developing multi-project based operations, is to have all project managers organized in a (multi-project) management system. The manager of project managers acts as a coordinator in the project realization of the company. The organizing of a multi-project management system leads to a more rational engagement of resources and a more effective achievement of objectives of the project realization of the company. Multi-project management system transforms the operative orientation of project managers in realizing the objective goals of a particular project towards a strategic orientation in realizing 
purpose-based goals of a project oriented development of the company's successful project-based operations.

In matrix organizational structure, the resources are controlled by the functional organizational units, which in essence are the logistics of project realization. Projects, in accordance with the project budget and project realization technology, have at their disposal the necessary material and human resources of the functional organizational units at the right time. Matrix organizational structure, by means of effective coordination of functional and project units, increases the efficiency of combining limited resources as well as the effectiveness of achieving the company's development goals i.e. it dynamically optimizes the company's business operations.

In today's conditions of an unstable environment and an accelerated scientific and technological development in which creative knowledge and innovation represent the fundamental factor of the company's competitiveness, the matrix organizational structure, due to its adaptability to the changing environment and the flexibility in using the broad spectrum of specialist knowledge of human resources, encourages the development of communication networks and participative management of the company's project oriented process development. The multidisciplinary cooperation of professionals and decentralized decision-making develop teamwork and organizational knowledge simultaneously lending itself for innovative creation of new products and technical specialization.

The fundamental problem of managing project processes within the matrix organizational structure is the crossing on the project and functional managements' chain of command. Dual responsibilities of project team members - horizontal, technologically to project managers, and vertical, disciplinary to function managers of organizational units in which they work on the realization of the functional activities cause conflicts between functional and project managers and thus conflicts of loyalty among project teams members (Zekić, 2007).

The project management needs to manage conflicts in a way that it directs them towards creative or innovative project problem solving. Managing conflict situations stimulates upgrading of knowledge, skills and impacts in innovation and thus conflict need not be seen as a negative side effect of matrix organizational structure, but, indeed, an advantage in the contemporary turbulent business conditions. The main role of management is creating a positive organizational climate i.e. the development of an entrepreneurial organizational culture that incorporates individual and group goals in order to achieve a company's project and business goals.

Regardless the features of complexity and conflict of the matrix organizational structure which requires a developed system of general and project management, its implementation has become inevitable in managing project processes of the strategic development of company's operations in today's dynamic environment. Successful implementation of the matrix organizational structure understands a dynamic matrix whose infrastructure is composed of information flows, as pre and post logistics material flows, driven by an entrepreneurial organizational culture as a catalyst for management and execution process of project realization.

\subsection{Network Organizational Structure and Project Management of a Company's Operations and Development}

Project management of a company's operations and development is characterized by innovation of management and execution of processes founded on continuous project-related organizational identification and problem solving related to the dynamic optimization of the company's business operations in today's conditions of constant changes within the ever more heterogeneous environment. The development of complex and flexible matrices as networks having no pronounced hierarchical structure of the management system and in which power i.e. knowledge is found at the organizational boundaries, becomes a precondition for the company's sustainability in the contemporary market (Hamel, 2009). The modern company, which operates primarily on the underlying process-based organized knowledge in project creation of added value for customers, at the right time, at the right place and at an acceptable price, requires the interconnectedness of all its segments in a single self-organizing, networked whole.

The network organizational structure develops a holistic approach to project-based management of a company's operations and development on the principles of participative project management. The network does not have a company structure (Omazić \& Baljkas, 2005); it represents an organic communication process in which all participants are equal, and in which the responsibility and power are distributed horizontally and procedurally. As a result of the exchange of information within the network, organizational knowledge and new structures teams are established.

An interconnection of networks is a prerequisite of formal organization. Information-based networking of process executors allows them to always know what is happening at the various steps within the process. Each team member, depending on his/her specialty, coordinates the problem solving in a particular problem area with the aim of continuing the effective functioning of the project realization process, thereby eliminating the need for 
a formal hierarchy. Project team members play the roles of managers depending on the situation and the nature of the problem. This hierarchy is temporary; it exists for as long as the problem exists, and once it is solved, it moves down horizontally to the next problem when another network node takes up the problem solving and assumes the new temporary managerial role (Figure 7).

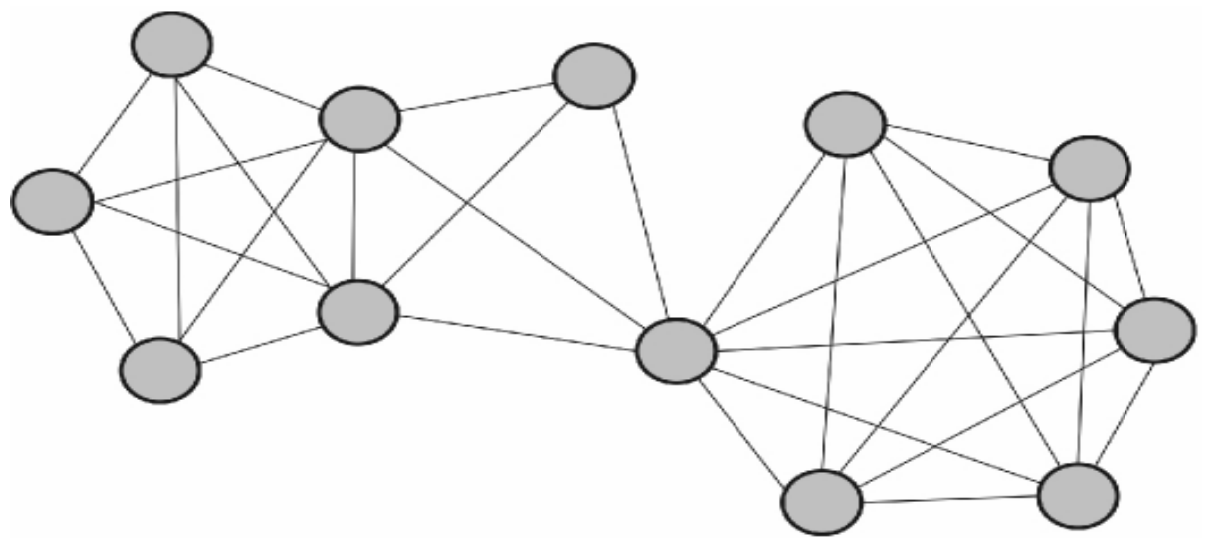

Figure 7. Network organization of project management

The non-hierarchical network system of participatory management which is based on organized knowledge in gathering and processing prior information needed for project identification and problem solving for the purpose of successful business performance, develops the preconditions for an effective anticipatory management of the dynamic optimization of a company's business operations through the implementation of known methods and techniques in managing project realization and realization of unique and time-limited business ventures with a planned realization technology and predictable cost-effectiveness in their exploitation. The system of the cascading indicators of cost-benefit analyses, from initiation and selection, through planning and realization, to evaluation and managerial control over individual projects and development programs, also provide an adequate information base for the strategic project management of dynamic optimization of a modern company's business operations.

\section{Cost-benefit Analysis of Project-based Business Performance}

In view of the development of an anticipative managerial control i.e. anticipatory management of the economics of realizing initiated projects within the strategic development program of a company's operations, the strategic project management during the selection process carries out the economic segment of the cost-benefit analysis which compares and evaluates the advantages and disadvantages of an individual project. The goal of the cost-benefit analysis is to determine the feasibility i.e. cost effectiveness of planned project realization of projects and exploitation of projects' products by comparing the costs and benefits at individual economic phases of project operations.

Economic and financial cost-benefit analysis evaluates and compares the profitability and liquidity of the realization of the initiated alternative projects and the company's defined strategic development program. Economic and financial flows of the project realization and exploitation of project products represent the information base of the economic cost-benefit analysis of project-based operations.

Financial flow (Table 1) shows the liquidity of an individual project and project operations development program i.e. it is an indicator of the possibility of financing the project and the project's contribution to strengthening the company's financial potential. The revenues in the financial flow provide information on the available financial means, whereas the expenditures, on liabilities due. An individual project is, like a company, liquid if its cumulative net income is constantly positive (Benedeković, 2007).

Incomes within the financial flow are business events that increase the financial potential of an individual project and project operations, regardless the source. Revenues are the result of project exploitation i.e. project commercialization, and therefore, simultaneously act on increasing the economic potential of the company. Other incomes, that come from the company's environment and enable the financing of project realization and exploitation, in periods when project income is not sufficient, increase the financial, but not the economic potential of the company. Income from the residual value of the project i.e. the value of assets at the end of the project's life-cycle, impact both the economic and the financial potential of the company. 
Table 1. Project/project-based operations financial flow

\begin{tabular}{llllll}
\hline \multirow{2}{*}{ Structure } & \multicolumn{5}{c}{ Period } \\
\cline { 2 - 6 } & 1 & 2 & 3 & 4 & 5 \\
\hline I. INCOME & 100 & 70 & 170 & 190 & 230 \\
1. Project revenues & - & 20 & 168 & 190 & 190 \\
2. Sources of financing & 100 & 50 & - & - & - \\
2.1. Own sources & 50 & 30 & - & - & - \\
2.2. Loans & 50 & 20 & - & - & - \\
3. Residual value of the project & - & - & 2 & - & 40 \\
II. EXPENDITURES & 100 & 68,5 & 130 & 140 & 170 \\
4. Investments & 100 & 50 & - & - & 10 \\
5. Project expenditures & - & 16 & 90 & 95 & 95 \\
6. Income tax & - & 0,5 & 15 & 18 & 18 \\
7. Dividends and annuities & - & 2 & 25 & 27 & 47 \\
III. NET INCOME & 0 & 1,5 & 40 & 50 & 60 \\
IV. CUMULATIVE & 0 & 1,5 & 41,5 & 91,5 & 151,5 \\
\hline
\end{tabular}

Expenditures in the financial flow of an individual project or project-based operations are business events that reduce the financial potential of the company, regardless their form and ownership. Investments and material expenditures simultaneously act upon the reduction of the economic potential of the company. Other expenditures are the result of the use of financial resources that have not been gained through project exploitation and actually represent the return of previously obtained financial means (annuities, dividends), and therefore, reduce only the financial and not the economic potential of the company.

The source of information for a dynamic assessment the profitability of a project and project-based operations is the economic flow of the project / project-based operations (Table 2) - the statement showing business events that affect the movement in the economic potential of a project and project-based operations. The economic flow, as opposed to financial, does not include funding sources in income, and neither does it include the loan repayment and dividend payment in expenditures. Moreover, the expenditures do not include depreciation, as it not considered a cost. Within the economic flow, net income is negative and represents the investment value in the period of project realization, while in the exploitation phase it shows dynamics of the return on investment.

Positive net income in a certain year of the project exploitation life-cycle is an indicator of indicator of increased economic potential of project operations in that year, whereas a negative one, the reduction of the economic potential. In order to assess the profitability of individual projects i.e. project-based operations, it is essential to consider whether the cumulative of net income is positive or negative i.e. whether the company's overall economic potential is increased or reduced, regardless the movements during individual years of the realization of the strategic business development program.

Table 2. Project/project-based operations economic

\begin{tabular}{llllll}
\hline \multirow{2}{*}{ Structure } & \multicolumn{5}{c}{ Period } \\
\cline { 2 - 6 } & $\mathbf{1}$ & $\mathbf{2}$ & $\mathbf{3}$ & $\mathbf{4}$ & $\mathbf{5}$ \\
\hline I. INCOME & - & 20 & 170 & 190 & 230 \\
1. Project revenues & - & 20 & 168 & 190 & 190 \\
3. Residual value of the project & - & - & 20 & - & 40 \\
II. EXPENDITURES & 100 & 66,5 & 105 & 113 & 123 \\
4. Investments & 100 & 50 & - & - & 10 \\
5. Project expenditures & - & 16 & 90 & 95 & 95 \\
6. Income tax & - & 0,5 & 15 & 18 & 18 \\
III. NET INCOME & -100 & $-46,5$ & 65 & 77 & 107 \\
IV. CUMULATIVE & -100 & $-146,5$ & $-81,5$ & $-4,5$ & $+102,5$ \\
\hline
\end{tabular}

The incomes in economic flow are those business events that increase, while expenditures, those that reduce the company's economic potential i.e. assets. As a result, there are no sources or liabilities towards the financing sources since their effect on the economic potential i.e. assets is neutral. Invested funds are returned to they are only of concern to the financial potential of a particular project i.e. company. Net income in within the economic flow indicates an increase or decrease in the economic potential of a particular project i.e. company. 
The anticipatory management of the dynamic optimization of project-based operations is possible if there is an adjusted combination of methods developed for managing the realization of individual projects. The first method shows the possibility of gaining real net cash income by project realization and exploitation, and enables a dynamic management of the liquidity of project-based operations i.e. a continuous approximation of cash flows, whereas the other, enables the management of the profitability of business operations i.e. shows the rate of return on invested capital in individual projects i.e. the company's project-based operations.

\subsection{Net Present Value Method - Absolute Accumulation of Project Realization}

This method of evaluating the financial viability of the company's project-based operations is considered the basic method of project oriented decision making. The net present value of the project i.e. the company's strategic development program is defined as the sum of annual net revenues within the economic flow reduced to its value in the first year of the project related operations (Orsag, 2002). Calculated free cash flow for each year is discounted to the present value with a default rate of return and this sum is then compared to the planned amount of investment which is considered as the initial cash flow.

$$
N S V=\sum_{n=1}^{t} N P_{n}^{e}\left[\frac{1}{1+\frac{p}{100}}\right]^{n}
$$

$\mathrm{NPV}=$ net present value

$\mathrm{NR}=$ net revenues in economic flow

$\mathrm{p}=$ discount rate

$\mathrm{n}=$ year within the realization of the strategic development program project, $\mathrm{n}=1 \ldots \mathrm{t}$.

The project or the system of synergically related projects within the company's project-based operations development program is acceptable according to the net present value method if its net present value is positive, and unacceptable, if it is negative. The resultant of all selected projects of the company's development program is an indicator of the final absolute accumulation of planned project realization of the strategy for company's business development i.e. an indicator of the company's value.

\subsection{Internal Profitability Rate Method - Relative Accumulation of Project Realization}

This method uses the internal profitability rate to establish the viability of investment made into a project's realization i.e. strategic program of company's project-based operations. The internal profitability rate is defined as the discount rate which equalizes the present value of income and expenditures or in other words, that which reduces to zero the net present value of a project i.e. strategic development program. It is calculated based on the following model:

$$
O=\sum_{n=1}^{t} N P_{n}^{e}\left[\frac{1}{1+\frac{p}{100}}\right]^{n}
$$

$\mathrm{NI}=$ net income in economic flow

$\mathrm{p}=$ internal profitability rate

$\mathrm{n}=$ year within the realization of the strategic development program project, $\mathrm{n}=1 \ldots \mathrm{t}$.

The basic criterion for assessing the eligibility of a project's and a strategic development program realization, based on the internal profitability rate method is that the internal profitability rate is higher than the default rate.

The internal profitability rate shows the average annual rate of return on invested capital and is the base for negotiating and contracting a maximally acceptable interest rate on loans for financing projects' realizations. It provides information on the average annual rate of project accumulation i.e. the project realization of the company, but not on the absolute amount of this accumulation. The information on the absolute amount of accumulation and income is provided by the net present value method, and therefore, it is necessary to combine these two methods in order to create a fuller picture of the absolute and relative success of project realization i.e. the success of the company's project-based operations.

By combining these basic methods of evaluating the viability of alternative projects realizations, which can, depending on the specific features of project realization and exploitation, be complemented by other methods, 
strategic project management can, in stable conditions, successfully select projects and define a strategic development program of project-based operations through deterministic decision-making at low risk. However, as the realization and exploitation of projects as unique target ventures takes place over a longer period of time, the actual values of certain variables are likely to move within a certain interval around their expected values in the future.

The future is stochastic, so it is necessary to have at one's disposal information on the sensitivity of projects and strategic development of project-based operations to the changes in the value of input variables. Sensitivity analysis provides information on how positively or negatively will the potential changes in some input variable impact the final results of project evaluation. The range of expected values of critical parameters and the probability of the occurrence of a certain value is determined by the possibility analysis.

The evaluation of the economic feasibility, i.e. viability of projects and project-based operations, is a fundamental, but not the sole, criterion for the selection of projects and the activation of the strategic program of project-based operations. The strategic project management decides on activating the realization of projects based on their overall contribution to the increase the dynamic success of a company's business performance. The real option method or the optional (opportunity) approach to project evaluation takes into account the qualitative factors of project realization and exploitation as well as the managerial flexibility in adapting project-based operations to changing business objectives, resources and technology during the realization of the company's strategic development program. This significantly reduces risk and increases the effectiveness of project management of a company's business operations and development.

\section{Conclusion}

Anticipatory project management of the dynamic harmony of the business operations of a company, as a socioeconomic system, and the changes in the influential environment, by means of continuous project realization of a balanced system of the company's stakeholders' goals, is a precondition of sustainability and the development of the company's competitiveness in today's turbulent environment. The dynamics of changes in all segments of the environment makes it almost impossible to successfully manage a company as an isolated economic system, through the traditional reactive approach. Proactive project management of changes, congruent to anticipative demands of key stakeholders, by means of a systematically organized managerial process of a project- based approach to development strategy, project realization of development programs and project exploitation of project products at a predefined dynamics and viability, is the managerial model of developing the company's competitiveness in the recent conditions of constant discontinuous changes in the environment. Managing a company as a project is the future that has already started, and which requires a complete change in the management paradigm and, accordingly, the change in the approach and the organization of the companies' management, which must be based on the principles of an innovative, participatory - project management with a pronounced social function and social responsibility.

\section{References}

Adizes, I. (2006). The Corporate Lifecycle. M.E.P. Consult, Zagreb.

Benedeković, J. (2007). Preparation and Assessment of Investment Projects. FOIP, Zagreb.

Gereis, R. (2002). Professional Project Portfolio Management. Roland Gareis Consulting, Vienna.

Hamel, G. (2009). Future of Management. Mate, Zagreb.

Hauc, A. (2007). Project Management and Project Oriented Business Operations. M.E.P. Consult, Zagreb.

Hauc, A., Bobek, S., Semolič, B., \& Treven, S. (1991). Strategic Management and Projects. Informator, Zagreb.

Kerzner, H. (2006). Project Management - A Systems Approach to planning, Scheduling and Controlling. John Wiley \& Sons Inc., New York.

Maylor, H. (2001). Beyond the Gantt Chart - Project Management Moving on. European Management Journal, $19(1)$.

Neverauskas, B., \& Čiutiene, R. (2011). The theoretical approach to project portfolio maturity management. Economics and management, Kaunas University of Technology.

Omazić, M. A., \& Baljkas, S. (2005). Project Management. Sinergija, Zagreb.

Orsag, S. (2002). Capital Budgeting - Assessment of Investment Projects. Masmedija, Zagreb.

Thomas, J., Delisle, C., \& Jugdev, K. (2001). Exploring the "Knowing-Doing” Gap in Project Management Or Seelling Project Management to Executives Phase II. Centre for Innovative Management, Athabasca 
University.

Xu, L., Tan, W., Zhen, H., \& Shen, W. (2008). An approach to enterprise process dynamic modeling supporting enterprise process evolution. Springer Science + Businesss Meia LLC.

Zekić, Z. (2007). Management - Entrpreneurial Technology. Faculty of economics, Rijeka.

Zekić, Z. (2010). Project Management - Managing Development Changes. Faculty of economics, Rijeka. 